\title{
Diagnosis of Subclinical Endometritis in Murrah Buffaloes through Cytobrush Technique
}

\author{
Ravi Dutt ${ }^{*}$, Gyan Singh ${ }^{2}$, Mahavir Singh ${ }^{3}$, Maneesh Sharma², \\ Jasmer Dalal $^{1}$ and R.K. Chandolia ${ }^{1}$ \\ ${ }^{1}$ Department of Veterinary Gynaecology and Obstetrics, ${ }^{2}$ Department of Veterinary Clinical \\ Complex, ${ }^{3}$ College Central Laboratory, Lala Lajpat Rai University of Veterinary and Animal \\ Sciences Hisar-125004, Haryana, India \\ *Corresponding author
}

\begin{tabular}{|c|c|}
\hline \multicolumn{2}{|r|}{ A B S T R A C T } \\
\hline & \multirow{7}{*}{$\begin{array}{l}\text { The objective of this study was to find out microbial cause of repeat breeding in ten repeat } \\
\text { breeder Murrah buffaloes at Government Livestock Farm, Sector-II, Hisar. The cytological } \\
\text { samples were obtained from these buffaloes' uterus using cytobrush technique and relating } \\
\text { the findings to the presence of polymorphonuclear cells, identification of bacteria and } \\
\text { antibiotic sensitivity pattern is reported. The subclinical endometritis was declared on the } \\
\text { basis of presence of } \geq 10 \% \text { polymorphonuclear cells in endometrial smears. Besides } \\
\text { Bacillus (5), mixed infection of Staphylococci }+ \text { E. coli }(3) \text {, Bacillus }+ \text { E. coli }(1) \text {, and } \\
\text { Proteus }+ \text { Bacillus (1) was also recorded. There was highest prevalence of Bacillus } \\
\text { (46.66\%) followed by E. coli ( } 26.67 \%) \text {, Staphylococci }(20.0 \%) \text { and Proteus }(6.66 \%) \text {. The } \\
\text { bacterial isolates reported in the present study showed highest sensitivity }(60 \%) \text { towards } \\
\text { Moxifloxacin and Enrofloxacin followed by Chloramphenicol and Gentamicin }(33.3 \%) \\
\text { and least towards Ceftriaxone and Cefoperazone (13.3\%). All the isolates showed } \\
\text { resistance towards Penicillin-G, Ofloxacin, Amoxicillin, Oxytetracycline, Ampicillin, } \\
\text { Neomycin, Amikacin, Cloxacillin and Cephalexin. The findings of the present study } \\
\text { revealed that cytobrush technique could preferentially be used to detect subclinical } \\
\text { endometritis in clinical practice. }\end{array}$} \\
\hline Keywords & \\
\hline $\begin{array}{l}\text { Buffalo, Cytobrush, } \\
\text { Cytology }\end{array}$ & \\
\hline Endome & \\
\hline Article Info & \\
\hline & \\
\hline & \\
\hline
\end{tabular}

\section{Introduction}

Uterine infections in dairy animals cause infertility in acute cases and sub-fertility in chronic cases. Consequently, uterine infection reduces conception rate, increase calving to conception interval and contribute for increased culling rate (Herath et al., 2006; Sheldon et al., 2009). During parturition, relaxation of the vulva and cervical dilation allow for the entry of bacteria into the uterus (Azawi, 2008) and hence, bacterial contamination of the uterus postpartum is common. Among the various bacteria that cause uterine infection the most common bacteria include Escherichia coli, Arcanobacterium pyogenes, Fusobacterium necrophorum and Prevotella sp. (Griffin et al., 1974; Sheldon et al., 2002) and are acquired from the faeces and faecal contamination of the coat, bedding and environment. Repeat breeding is a major cause of infertility in the dairy animals. Among various aetiologies of repeat breeding, 
subclinical endometritis is an important cause and is often undiagnosed. Diagnosis of subclinical endometritis as early as possible may reduce the cost of rearing the buffaloes at dairy farm or individual farmer. The various methods for diagnosing endometritis involve uterine biopsies, lavage and swabs are existing but these may cause irritation and distortion of cells (Singh et al., 2016). An inconsistent success following conventional therapies is achieved due to lack of diagnostic standards (Kasimanickam et al., 2005). Therefore, most of the recent studies have been focused on sophisticated diagnosis of endometrial alterations beyond clinical signs of endometritis at field level. A novel approach for uterine cytological examination by using cytobrush technique which is considered consistent and reliable method in dairy animals (Barlund et al., 2008 and Honparkhe et al., 2014). Under field conditions cervico-vaginal discharge hanging from vulvar lips is generally collected for assessment of uterine health which in majority of cases gives false reflection of uterine environment. Keeping this in view, the present study was designed to investigate the efficacy of cytobrush technique in diagnosing subclinical endometritis in repeat breeder Murrah buffaloes at an organized farm.

\section{Materials and Methods}

Ten apparently healthy, cyclic pleuriparous Murrah buffaloes which had been inseminated consecutively in more than three estrous cycles with semen of elite bulls and exhibited conception failure at Government livestock farm, Sector II, Hisar were selected for the study. The animals had also been administered GnRH agonists at the time of artificial insemination to ensure ovulation at proper time. The cervico-vaginal discharge of all the animals was apparently normal. All selected animals were examined per-rectally and administered Cloprostenol $500 \mu \mathrm{g}$ three days earlier to induce the estrus and it also allowed the passage of cytobrush assembly with ease. The cytobrush technique was applied in all the buffaloes for endometrial cytology for confirmation of subclinical endometritis.

The cytobrush assembly (especially fabricated for bovine contains intrauterine catheter and a stilette attached with cytobrush (Fig. 1) was introduced into vagina and then through the cervix to body of the uterus and then screwed gently in both directions. Immediately after removal from reproductive tract, the cytobrush was smeared on clean sterilized glass slides. The slide was fixed in methanol for one minute and stained with Field's stain with slight modification (3-4 dips in Soln. A and B). The slide was observed first under microscope under $100 \mathrm{X}$ and then under oil immersion (1000 X magnification) by counting 100 cells to determine the percentage of polymorphonuclear cells. Each slide was read by two persons and the average of the readings was considered. A buffalo was considered to be suffering from subclinical endometritis, if the proportion of polymorphonuclear cells (PMNs) was greater than 10 per cent as suggested by Kasimanickam et al., (2004). The cytobrush samples were immediately dipped into sterile tubes containing the brain heart infusion (BHI) broth and transported to the laboratory within 1 to 2 hours and kept in an incubator for 24 hours at $37^{\circ} \mathrm{C}$. The BHI broth was then checked for the turbidity and using a sterilized loop the broth culture was streaked onto BHI and selective media viz., 5\% defibrinated sheep blood agar plate and MacConkey lactose agar plate and incubated aerobically at $37^{\circ} \mathrm{C}$ for $16-18$ hours. The microbes were identified by colony morphology, Gram staining and primary biochemical tests. The standard disc diffusion method (Bauer et al.,1966) was employed for carrying out 
antimicrobial sensitivity test using 15 antimicrobials viz., ampicillin $(25 \mathrm{mcg})$, ceftriaxone $(10 \mathrm{mcg})$, amoxicillin $(10 \mathrm{mcg})$, cephalexin $(30 \mathrm{mcg})$, cloxacillin $(30 \mathrm{mcg})$, chloramphenicol $(25 \mathrm{mcg})$, neomycin (30 $\mathrm{mcg}$ ), ofloxacin (5 mcg), enrofloxacin (10 $\mathrm{mcg})$, cefoperazone $(75 \mathrm{mcg})$, amikacin $(10$ $\mathrm{mcg}$ ), penicillin $\mathrm{G}$ (10 units), gentamicin (30 $\mathrm{mcg})$, moxifloxacin (5 $\mathrm{mcg})$ and oxytetracycline $(30 \mathrm{mcg}) \quad(\mathrm{Hi}$ media, Mumbai). Zones of inhibition were measured and the results were interpreted as sensitive (S) and resistant (R) using the chart provided by manufacturer.

\section{Results and Discussion}

The examination of slides under microscope at $100 \mathrm{X}$ and then under oil immersion $(1000$ $\mathrm{X}$ magnification) by counting 100 cells to determine the percentage of polymorphonuclear cells that revealed presence of $\geq 10 \%$ polymorphonuclear cells (Table 1, Fig. 2a and 2b).

Kasimanickam et al., (2004) found $>18 \%$ neutrophils at 20-33 days postpartum or $>10$ $\%$ neutrophils at 34-47 days postpartum in uterine samples as an indicative of subclinical endometritis whereas, Gilbert et al., (2005) found $5 \%$ neutrophils at 40 to 60 days postpartum as an indicator of subclinical endometritis in cattle, while Barlund et al., (2008) used a neutrophil threshold value of $8 \%$ at 28-41 days postpartum in cattle to declare endometritis. Various research studies have supported that endometrial cytology by cytobrush technique is most efficient and early diagnostic technique when used along with microbial assay for diagnosis of subclinical endometritis (Honparkhe et al., 2014; Bajaj et al., 2015). The subclinical endometritis was declared on the basis of clear mucus discharge and $\geq 10 \%$ polymorphonuclear cells (PMN) whereas clinical endometritis diagnosed on the basis of mucopurulent discharge Kasimanickam et al., (2004).

In the present study, a total of 15 organisms were isolated from ten samples. Besides Bacillus (5), mixed infection of Staphylococci + E. coli (3), Bacillus + E. coli (1), and Proteus + Bacillus (1) was also reported. There was highest prevalence of Bacillus (46.66\%) followed by E. coli (26.67\%), Staphylococci (20.0\%) and Proteus (6.66\%).

The bacterial isolates reported in the present study showed highest sensitivity (60\%) towards Moxifloxacin and Enrofloxacin followed by Chloramphenicol and Gentamicin (33.3\%) and least towards Ceftraixone and Cefoperazone (13.3\%). All the isolates showed resistance towards Penicillin-G, Ofloxacin, Amoxicillin, Oxytetracycline, Ampicillin, Neomycin, Amikacin, Cloxacillin and Cephalexin (Table 2).

Similar to our findings, Singh et al., (2016) also reported highest prevalence of bacilli (47.94\%) followed by E. coli $(24.65 \%)$ and Staphylococcus $(12.32 \%)$ in the subclinical endometritis in dairy cattle. While in another study, E. coli was the most prevalent pathogen followed by Klebsiella, Proteus, Pseudomonas and Clostridium spp. (Udhayavel et al., 2013). Moges et al., (2013) reported higher prevalence of $A$. pyogenes followed by Streptococcus Sp. and E. coli, S. aureus, Klebsiella Spp. and C. fetus. In a study conducted by Sahadev et al., (2017), most common single isolate observed was $E$. coli $(45.71 \%)$ in 16 out of 35 cows followed by Staphylococcus (42.86\%), Proteus spp. and Enterobacter sp. (5.71\%). 
Fig.1 Cytobrush assembly and cytobrush

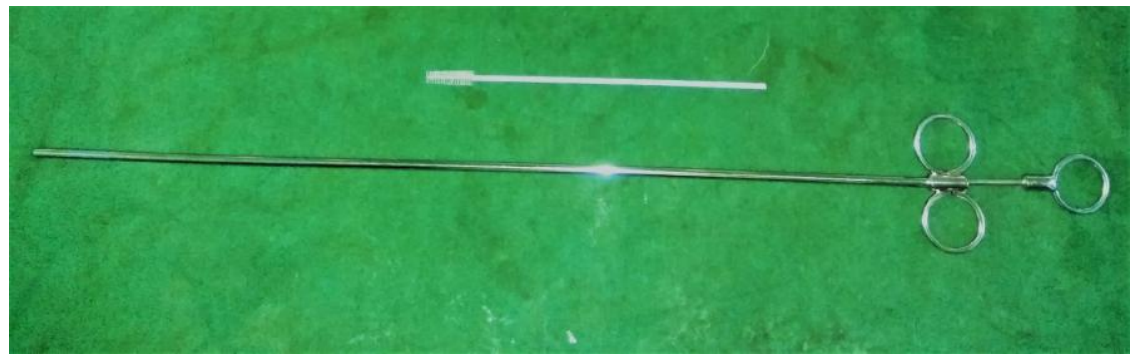

Fig. 2a and 2b Microscopic examination of Polymorphonuclear cells

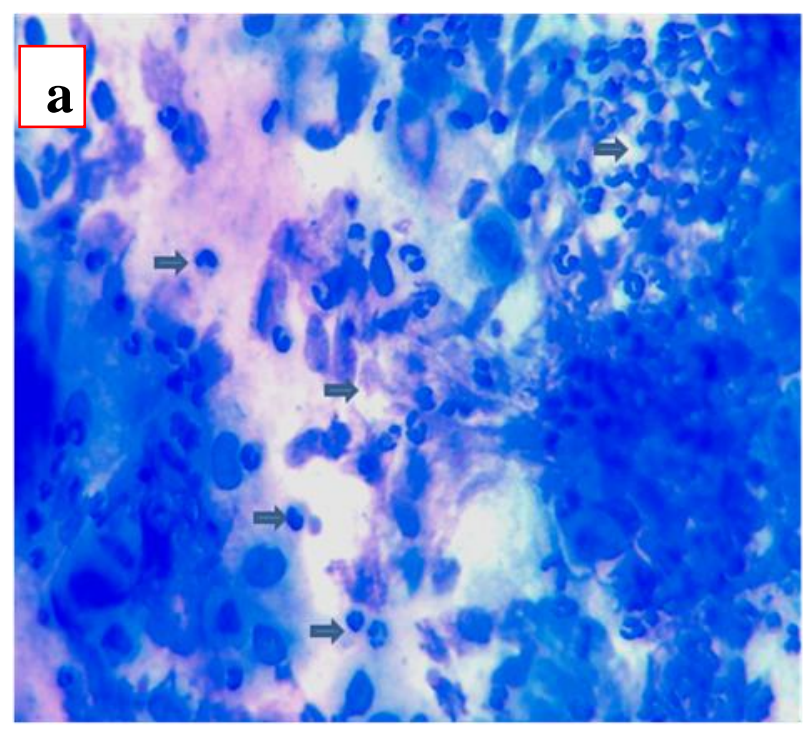

Fig. 2a: Polymorphonuclear cells (Arrows) in field's staining X100.

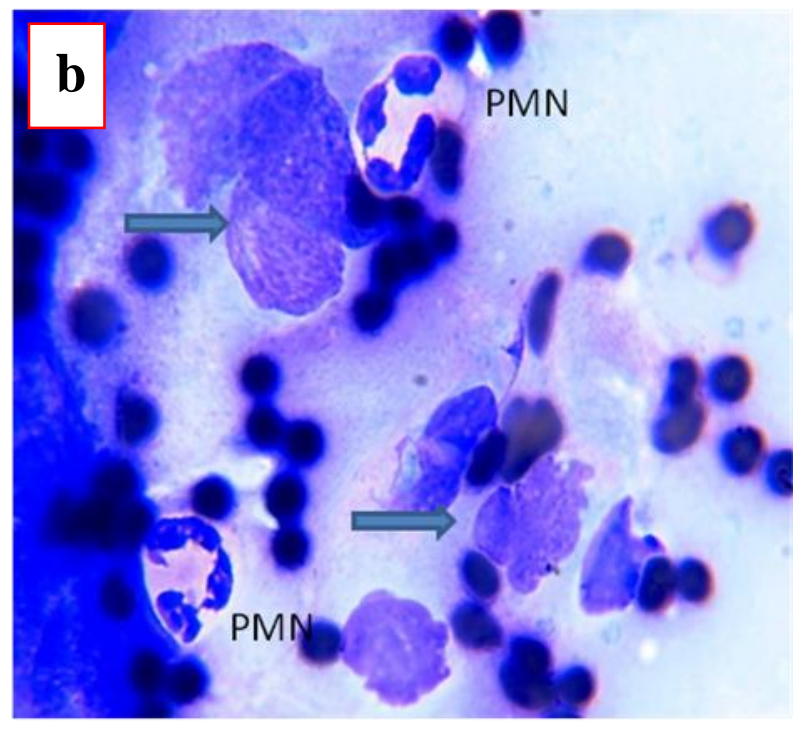

Fig. 2b: Polymorphonuclear cells and endometrial cells (Arrows) in field's staining X1000.

Table.1 Microscopic count of Polymorphonuclear cells (X1000)

\begin{tabular}{|c|l|c|}
\hline Sr. No. & Buffalo No. & Polymorphonuclear cell count (\%) \\
\hline 1 & $2667 / 355$ & 12 \\
\hline 2 & $2675 \mathrm{CM} / 167$ & 14 \\
\hline 3 & $2672 / 339$ & 12 \\
\hline 4 & $2676 / 194$ & 35 \\
\hline 5 & $2674 \mathrm{CM} / 212$ & 10 \\
\hline 6 & $2673 \mathrm{CM} / 310$ & 25 \\
\hline 7 & $2671 \mathrm{CM} / 113$ & 20 \\
\hline 8 & $2670 \mathrm{CM} / 317$ & 12 \\
\hline 9 & $2669 \mathrm{CM} / 072$ & 15 \\
\hline 10 & $2668 \mathrm{CM} / 187$ & 15 \\
\hline
\end{tabular}


Table.2 Bacteriology of subclinical endometritis and in vitro antimicrobial sensitivity of the isolates in Murrah buffaloes

\begin{tabular}{|c|c|c|c|c|c|c|c|c|c|c|c|c|c|c|c|c|}
\hline \multirow[t]{2}{*}{ Bacteria } & \multirow{2}{*}{$\begin{array}{l}\text { No. of } \\
\text { isolates }\end{array}$} & \multicolumn{15}{|c|}{ No. of isolates sensitive to } \\
\hline & & $\mathrm{P}$ & Of & Amx & $\mathrm{Ctr}$ & $\mathrm{O}$ & Amp & $\mathrm{N}$ & $\mathrm{Ak}$ & Cox & $\mathrm{Cpz}$ & Mox & Ex & $\mathrm{C}$ & G & $\mathrm{CN}$ \\
\hline Bacillus & 7 & 0 & 0 & 0 & 1 & 0 & 0 & 0 & 0 & 0 & 1 & 6 & 6 & 5 & 5 & 0 \\
\hline E.coli & 4 & 0 & 0 & 0 & 1 & 0 & 0 & 0 & 0 & 0 & 1 & 2 & 2 & 0 & 0 & 0 \\
\hline Staph. & 3 & 0 & 0 & 0 & 0 & 0 & 0 & 0 & 0 & 0 & 0 & 1 & 1 & 0 & 0 & 0 \\
\hline Proteus & 1 & 0 & 0 & 0 & 0 & 0 & 0 & 0 & 0 & 0 & 0 & 0 & 0 & 0 & 0 & 0 \\
\hline Total & 15 & 0 & 0 & 0 & 2 & 0 & 0 & 0 & 0 & 0 & 2 & 9 & 9 & 5 & 5 & 0 \\
\hline$\%$ sensit & ity & 0 & 0 & 0 & 13.3 & 0 & 0 & 0 & 0 & 0 & 133 & 60 & 60 & 33.3 & 33.3 & 0 \\
\hline
\end{tabular}

P-Penicillin; Of-Ofloxacin; Amx-Amoxycillin; Ctr-Ceftriaxone; O-Oxytetracycline; Amp-Ampicillin; N-Neomycin; Ak-Amikacin; Cox-Cloxacillin; Cpz-Cefoperazone; Mox-Moxifloxacin; Ex-Enrofloxacin; C-Chloramphenicol; GGentamicin, CN-Cephalexin

In an another detailed study, Gani et al., (2008) taken 51 uterine biopsy samples collected from 14 normal fertile and 37 repeat breeding cows for bacteriological examinations to find out the prevalence of bacterial flora and their role in repeat breeding syndrome. They found among 37 that suffered from repeat breeding, 23 samples (62.2\%) yielded 54 bacterial isolates; where Staphylococcus was predominant 14 (37.8\%), followed by Bacillus 13 (35.1\%), E. coli 11 (29.7\%), Pseudomonas 7 (18.9\%) while Gram negative minute rod shaped bacteria was $9(24.3 \%)$.

Muneer et al., (1991) and Bhat and Bhattacharyya (2012) reported oxytetracycline to be the best antibiotic for the treatment of metritis in cows. Findings of present study showed highest sensitivity towards Moxifloxacin and Enrofloxacin followed by Chloramphenicol and Gentamicin and least towards Ceftraixone and Cefoperazone against isolates of bacteria causing subclinical endometritis in Murrah buffaloes.

Indiscriminate use of antibiotics, irregular doses of antibiotics or under dosing of antibiotics may lead to development of resistance in microbes which creates major challenge for pharmaceuticals and veterinary practitioners. Therefore, antibiotic sensitivity should be carried out to find the most effective drug.

The present study clearly indicated that there is high degree of correlation between polymorphonuclear cells and bacterial infection in the uterus. If PMN cell count is more than $10 \%$, the chances of subclinical endometritis are highly evident. There was highest prevalence of Bacillus (46.66\%) followed by E. coli (26.67\%), Staphylococci (20.0\%) and Proteus (6.66\%).

\section{Acknowledgement}

The authors acknowledge the Sector superintendent and Veterinary Surgeon, Dr. Satpal Selwal, Government Livestock Farm, Sector-II, Hisar (Haryana) for providing opportunity for this study and Incharge, College Central Laboratory, Lala Lajpat Rai University of Veterinary and Animal Sciences, Hisar (Haryana) for providing facilities for microbiological studies.

\section{References}

Azawi, O. I. 2008. Post-partam uterine infection in cattle. Anim. Reprod. Sci., 105(3-4):187-208.

Barlund, C.S., Carruthers, T.D., Waldner, C.L. and Palmer, C.W. 2008. A comparison of diagnostic techniques for postpartum endometritis in dairy cattle. Theriogenol., 69: 
714-723.

Bauer, A.W., Kirby, W.M., Sherris, J.C. and Turck, M. 1966. Antibiotic susceptibility testing by a standardized single disc method. Am. J. Clin. Pathol., 45: 493-496.

Bhat, F.A. and Bhattacharyya, H.K. 2012. Management of metritis in crossbred cattle of Kashmir using oxytetracycline, cephalexin and Prostaglandin $\mathrm{F}_{2 \alpha}$. Indian J. Anim. Res., 46 (2): 187-189.

Gani, M. O., Amin, M. M., M. Alam, G. S., Kayesh, M. E. H., Karim, M. R., Samad,, M. A. and Islam, M.R. 2008. Bacterial flora associated with repeat breeding and uterine infections in dairy cows. Bangladesh Journal of Veterinary Medicine. 6(1): 79-86.

Gilbert, R.O., Shin, S.T., Guard, C.L., Erb, H.N. and Frajblat, M. 2005. Prevalence of endometritis and its effects on reproductive performance of dairy cattle. Theriogenol., 64: 1879-1888.

Griffin, J., Hartigan, P. and Nunn, W. 1974. Infection patterns and endometritis during the first seven weeks post-partum. Theriogenol., 1(3):91-105.

Herath, S., Fischer, D.P., Werling, D., Williams, E. J., Lilly, S. T., Dobson, H., Bryant, C. E., Sheldon, I. M. 2006. Expression and function of Toll-like receptor 4 in the endometrial cells of the uterus. Endocrinol., 147: 562-570.

Honparkhe, M., Ghuman, S. P. S., Singh, J., Dhindsa, S. S., Kumar, A., Chandra, M. and Brar, P. S. 2014. Diagnosing subclinical endometritis through uterine cytobrush cytology and its treatment with proteolytic enzymes in buffaloes. In: XXIX Annual Convention of ISSAR on "Frontier Reproductive Biotechnologies for Enhancing Animal Fertility and Fecundity: Global Perspective", held at Maharashtra Animal and Fishery Sciences University, Nagpur, Maharashtra, Jan. 8-10, RFF 024, pp 131. RFF 055 pp 147.

Kasimanickam, R., Duffield, T. F., Foster, R. A., Gartley, C. J., Leslie, K. E., Walton, J. S. and Johnson, W. H. 2005. A comparison of cytobrush and uterine lavage techniques to evaluate endometrial cytology in clinically normal postpartum dairy cows. Canadian Vet. J., 46: 255-259.

Kasimanickam, R., Duffield, T.F., Foster, R.A., Gartely, C.J., Leslie, K.E., Walton, J.S. and Johnson, W.H. 2004. Endometrial cytology and ultrasonography for detection of subclinical endometritis in postpartum dairy cattle. Theriogenol., 62: 9-23.

Moges, N., Regassa, F. Yilma, T. and Unakal, C. G. 2013. Isolation and antimicrobial susceptibility of bacteria from dairy cows with clinical endometritis. J. Reprod Infertil., 4: 4-8.

Muneer, M.A., Arshad, M., Ahmad, M., Ahmad, I., Rauf, A. and Abbas, S. 1991. Antibiotic sensitivity of bacteria causing metritis in cows. Pakistan Vet. J., 11:78-81.

Sahadev, A., Krishnaswamy, A., Sudha, G., Narayana Bhat, M., M. Narayanaswamy, M., Nagaraja, B.N. and Suryanarayana. 2017. Studies on aerobic bacterial flora associated with postpartum subclinical endometritis in crossbred dairy cows. Int. J. Curr. Microbiol. App. Sci., 6(7): 2352-2357.

Sheldon, I. M., Price, S. B., Cronin, J., Gilbert, R. O. and Gadsby, J. E. 2009. Mechanisms of infertility associated with clinical and subclinical endometritis in high producing dairy cattle. Reprod. Dom. Anim., 44 (3): 1-9.

Sheldon, I., Noakes, D., Rycroft, A. and Dobson, H. 2002. Effect of postpartum manual examination of the vagina on uterine bacterial contamination in cows. Vet. Rec., 151: 531534.

Singh, J., Honparkhe, M., Chandra, M., Kumar, A., Ghuman, S.P.S. and Dhindsa, S.S. 2016. Diagnostic efficacy of uterine cytobrush technique for subclinical endometritis in cross-bred dairy cattle. Indian Vet. J., 93 (02): $11-13$.

Udhayavel S., Malmarugaa, S., Palanisarnv, K. and Rajeswar, J. 2013. Antibiogram pattern of bacteria causing endometritis in cows. Vet. World. 6(2): 100- 102.

\section{How to cite this article:}

Ravi Dutt, Gyan Singh, Mahavir Singh, Maneesh Sharma, Jasmer Dalal and Chandolia, R.K. 2017. Diagnosis of Subclinical Endometritis in Murrah Buffaloes through Cytobrush Technique. Int.J.Curr.Microbiol.App.Sci. 6(11): 494-499. doi: https://doi.org/10.20546/ijcmas.2017.611.059 